\title{
Working with School-Age Children: Promoting Friendship ${ }^{1}$
}

Millie Ferrer and Anne M. Fugate ${ }^{2}$

\section{The Importance of Friendship}

Friends are vital to school-age children's healthy development. Research has found that children who lack friends can suffer from emotional and mental difficulties later in life. Friendships provide children with more than just fun playmates. Friendships help children develop emotionally and morally. In interacting with friends, children learn a lot of social skills, such as how to communicate, cooperate,

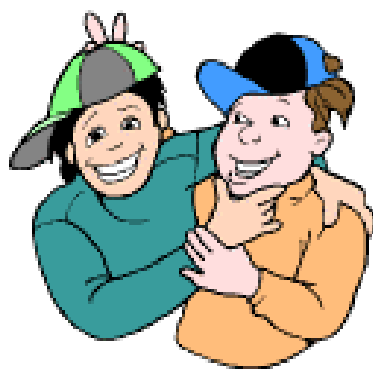
and solve problems. They practice controlling their emotions and responding to the emotions of others. They develop the ability to think through and negotiate different situations that arise in their relationships. Having friends even affects children's school performance. Children tend to have better attitudes about school and learning when they have friends there. In short, children benefit greatly by having friends.

\section{What Adults Can Do To Promote Children's Friendship}

The activities children participate in outside of school, such as afterschool programs, 4-H, scouts, and sport team, provide good opportunities for making friends, especially since they bring children together by common interests. Whether you work in an afterschool program, volunteer with 4-H or the scouts, or are involved in another youth program, you can play an important role in children's social and emotional development by being mindful of the importance of friendship. You can promote friendships by helping children learn the social skills for making and keeping friends. You can also create a safe, enriching environment in which friendships can flourish.

Fundamentally, adults lay the foundation for children to make friends by building positive, supportive relationships with them. Children begin to develop the basic trust and selfconfidence necessary to go out and meet others as infants, through a warm relationship with

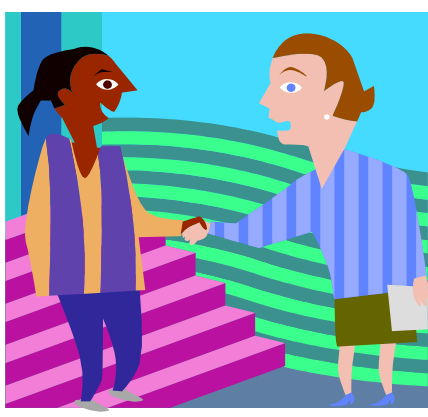
their parents. As children grow older, they continue to rely on their parents' support, but they also benefit from the support of other trusted adults. Try to develop a positive relationship with each child you work with. Greet each child warmly and let him know you are glad to see him. Ask the child about his day or what is going on in his life. By developing a positive relationship with a child, you are sending him the message that he is a worthwhile person, someone others like to be around.

1. This document is FCS2206, one of a series of the Department of Family, Youth and Community Sciences, Florida Cooperative Extension Service, IFAS, University of Florida, Gainesville FL 32611: Published: June 2003. Reviewed by Elaine Shook, extension agent IV, Tallahassee, FL and Judy Butterfield, extension agent III Starke, FL Please visit the EDIS Web site at http://edis.ifas.ufl.edu

2. Millie Ferrer, Ph.D., professor; and Anne M. Fugate, M.Ed., former coordinator Educational/Training Programs, Department of Family, Youth and Community Sciences, Cooperative Extension Service, IFAS, University of Florida, Gainesville, 32611.

The Institute of Food and Agricultural Sciences is an equal opportunity/affirmative action employer authorized to provide research, educational information and other services only to individuals and institutions that function without regard to race, color, sex, age, handicap or national origin. For information on obtaining other extension publications, contact your county Cooperative Extension Service office. Florida Cooperative Extension Service/Institute of Food and Agricultural Sciences/University of Florida/Christine Taylor Waddill, Dean. 
Adults also help children make friends by being a good role model. Children learn a lot of social skills from how adults interact with them and other people. To help the children you work with learn how to be people others like to be around, show them with your own actions. Talk to the children kindly and respectfully. Tell good-natured stories and jokes. Include everyone in conversations and activities. Be a good sport whether you win or lose.

You can do a great deal to prepare a child to make friends by maintaining a warm relationship with her and being a good role model. Below are some additional ways you can promote friendship in your program, group, or club.

\section{Set clear rules for appropriate behavior.} Children learn social skills in part through rules about how to treat others. For example, they learn how to share toys and settle arguments without hitting.

Involve the children in setting the group's rules. As your group makes its rules, keep a couple of guidelines in mind. First, limit the number of rules. Have just enough to make it clear how people and property should be treated. To limit the number, do not make a rule for every action. Instead, make a general rule that covers several actions. For example, instead of making the separate rules "no name calling" and "no teasing," make the rule "respect each other."

Also, state rules positively. Rules need to tell the children more than what not to dothey need to tell them what to do instead. For example, instead of "no hitting or kicking," state the rule as "keep your hands to yourself."

As your group makes its rules, discuss what each one means. Have the children give you examples of behaviors covered by each one.
When the children are involved in making their rules, they will not only be more likely to follow them, but they will also better understand the reasons for the rules and the standards for appropriate behavior.

When you need to apply consequences for breaking a rule, remember that children will imitate your actions. How you treat a child when he breaks a rule will influence how he responds to others. Avoid being harsh and punitive. Instead, be firm, kind, and respectful when you express your expectations of him.

Teach children how to solve conflicts. Many times children try to settle conflicts inappropriately because they do not have the necessary social skills. Being able to work out conflicts is an important skill in getting along with others. Depending on the circumstances in which you work with children, you might want to teach the whole group how to solve conflicts or coach children through it as the need arises.

When children talk to you about how they are feeling, listen. Show you are listening by reflecting what they say. For example, say, "Justin, it sounds like you're mad at Jamie. Jamie, it sounds like you are mad, too." Then, gently coach the children in solving their conflict. First, help the children identify the situation. For example, say, "Justin, it sounds like you're upset because Jamie didn't include you in the game. Jamie, it sounds like you didn't want to interrupt the game right when Justin asked." Then help them brainstorm solutions to the situation. Talk about the solutions they come up with. Which solutions works for both of them? If both agree on a safe solution, let them use it.

In general, try to avoid getting involved in children's conflicts. If you overhear children having a conflict, let them work it out on their own. Only step in if it is really necessary, if, for example, an argument is getting physical. 
Help children develop empathy. Around the age of six or seven, children are more able to understand others' feelings and points of view. Help children develop this ability by talking about different situations. For example, when children talk to you about a situation at school or a situation they hear about on the

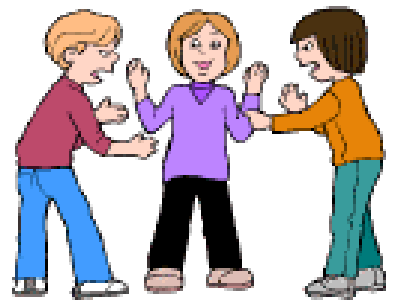
news, ask how they think the people felt and why they acted as they did. When dealing with conflict among the children you work with, ask them to describe the others' feelings and points of view.

\section{Give children opportunities to practice} cooperation and problem solving. Have children work on projects together or play games that require cooperation and group problem solving skills. For example, races in which teams are given an odd assortment of materials to complete a task are fun and provide plenty of practice in teamwork. You might even want to take such activities a little further with followup questions such as "In what ways did your team work well together? In what ways didn't you work well together? What might you do differently next time?" For ideas, see books such as The Second Cooperative Sports and Games Book by Terry Orlick, Energizers and Other Great Cooperative Activities for All Ages by Carol Apacki, and Team-Building Activities for Every Group by Alanna Jones.

\section{Encourage children to show support and} appreciation for others. You can encourage children to do this by setting the example for them, by modeling the behavior. For example, you could tell a child, "I appreciate the way you showed the new girl around and made her feel welcome" or "I like the way you hustled out there. You really helped the team." Depending on your group, you may want to include a more regular or formal show of support and appreciation, such as a special-person bulletin board or an appreciation circle. These kinds of activities enable each child in the group to receive and show support at some time.

Help children develop skills valued by their peer group. For example, being able to play sports tends to be important for school-age children. They do not have to be a superstar, but it is easier to join in and have fun if they know the rules and have the basic skills. If you work in an afterschool program, you might know a child or two who would like to join in games but have a hard time because of a lack of skills. You could help these children develop their skills by offering to kick the ball around with them yourself or by enlisting a volunteer to help. Just make sure not to pressure a child into anything she does not want to do. The pressure will only make her feel inferior. Make sure not to let the practice become a drill or drudgery. Be encouraging and focus on the fun of learning or playing together.

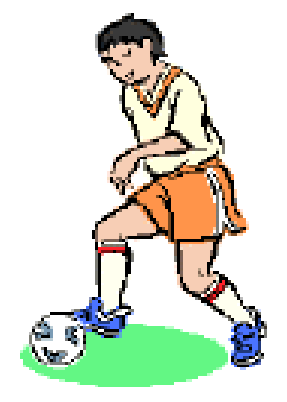

\section{Conclusion}

If you are concerned about a child in your program or group making enough friends, stop to consider whether the child just has a different social style. For example, the child may prefer one or two close friends rather than a wide circle of friends. One style is not better than another. What matters is that the child is comfortable and happy with his friends.

If it seems that the child has no friends, consider sharing your concern with the child's parents. Start out on a positive note by talking about some of the child's good qualities. Then, share with the parents what you observe happening. Make sure you express genuine concern for the child's overall well-being. You might suggest that the parents talk to the child's teacher, school counselor, or family counselor for additional guidance and resources. 
Whether you work with children in an afterschool program, 4-H club, scouts, or other youth program, you play an important role in their social development. Your support and the safe, accepting environment you create make it possible for children to meet new people and make friends. Friendships are very important to school-age children. They help children develop the self-confidence and social skills they will need as adults.

\section{References}

Asher, S., and Williams, G. (1996). Children without friends, parts 1-4. From Day Care Centers Connections from University of Illinois Cooperative Extension Service. Retrieved November 18, 2002 from the National Network for Child Care _Web sitee: http://www.nncc.org/Guidance/dc26 wo.friendsi 1.html.'

Brooks, J. (1999). The process of parenting, $5^{\text {th }} \mathrm{ed}$. Mountain View, CA: Mayfield Publishing Co.
Fabes, R., and Martin, C. (2001). Exploring development through childhood. Boston, MA: Allyn \& Bacon.

Ford Arkin, C. (1997). Children's friendships. From Backpack Buddies series from The Ohio State University Extension Service. Retrieved November 18, 2002 from the CYFERNet Web site: http://ohioline.osu.edu/bb-fact/pdf/bb-f8.pdf.

Gottman, P. (1997). Raising the emotionally intelligent child. New York, NY, Simon \& Schuster.

Hamner, T., and Turner, P. (2001). Parenting in contemporary society, $4^{\text {th }} \mathrm{ed}$. Boston, MA: Allyn \& Bacon

Patten, P. (1996). Developing Social Skills. Retrieved January 14, 2003 from the National Network for Child Care Web site: 'www.nncc.org/Guidance/dc14 develop.social.sk' ill.htmli 